\title{
DAYA SAING USAHATANI PEMBESARAN IKAN LELE PETANI PEMODAL KECIL DI KOTA PEKANBARU-RIAU
}

Small-Scale Catfish Farming Competitivenessin Pekanbaru-Riau

\author{
HERIYANTO HERIYANTO $* 1$, ASROL ASROL ${ }^{2}$, \& HAJRY ARIEF WAHYUDY ${ }^{3}$ \\ ${ }^{1.2,3}$ Program Studi Agribisnis, Fakultas Pertanian Universitas Islam Riau, Indonesia \\ Jl. Kaharuddin Nasution No. 113 Pekanbaru. 28284 \\ Email: heriyanto@agr.uir.ac.id
}

\begin{abstract}
ABSTRAK
Indonesia adalah negara yang memiliki tingkat produksi ikan cukup tinggi setiap tahunnya, disampaikan oleh Menteri Perikanan dan Kelautan bahwa Indonesia menyediakan pasokan ikan yang cukup ke luar negeri. Indonesia menduduki peringkat kedua di negara pengekspor ikan di dunia setelah Cina. Berdasarkan uraian secara umum, penelitian ini bertujuan untuk: Menganalisis daya saing ikan lele pembesaran. Adapun spesifikasinya, penelitian ini bertujuan untuk 1) menganalisis mengetahui karakteristik petani, 2) menganalisis daya saing bisnis pembesaran ikan lele, 3) untuk menganalisis dampak kebijakan pemerintah terhadap output dan input dalam bisnis memperbesar ikan lele . Penelitian ini dilakukan dengan medtoda survei di Kecamatan Rumbai Pesisir Kota Pekanbaru dengan jumlah sampel 15 responden. Untuk menjawab tujuan penelitian dianalisis statistik deskriptif dan analisis Kebijakan Analisis Matriks (PAM). Berdasarkan hasil penelitian menunjukkan bahwa Pertama: karakteristik rata-rata petani 41 tahun, pendidikan rendah, pengalaman bertani 8 tahun, rata-rata kepemilikan tanah 0,19 hektar. dan rata-rata jumlah anggota keluarga tiga orang. Kedua: Perusahaan pembesaran ikan lele di Kecamatan Rumbai Pesisir Kota Pekanbaru pada investor kecil memiliki keunggulan kompetitif yang ditandai dengan PCR ikan lele $<1$ dari 0,55 dan keunggulan komparatif tinggi yang ditandai dengan DRCR $<10,37$. Ketiga: kebijakan pemerintah dalam bentuk fasilitas produksi yang dapat diperdagangkan memberikan manfaat bagi memperbesar bisnis petani lele
\end{abstract}

Kata Kunci: Daya Saing, Lele, Input-Output, Analisis PAM

\begin{abstract}
Indonesia is a country that has a level high enough fish production annually, submitted by the Minister of Fisheries and Maritime Affairs that Indonesia provides enough supply of fish to foreign countries. Indonesia was ranked second in the fish exporting country in the world after China. Based on the description in general, this study aims to: Analyze the competitiveness of enlargement catfish. As for the specifics, this study aims to 1) analyze know the characteristics of the farmers, 2) analyze the competitiveness of the business of enlarging catfish, 3) to analyze the impact of government policies on output and input in the business of enlarging catfish. This study is a survey in Rumbai Pesisir sub district Pekanbaru City with a sample size of 15 respondents. To answer the research objectives are analyzed descriptive statistics and analysis Policy Analysis Matrix (PAM). Based on the results of the research shows that the First: characteristics of the average farmer 41 years of age, low education, a farming experience of 8 years, an average of 0.19 hectares of land ownership. and the average number of family members of three people. Second: Enterprise's enlargement catfish in Rumbai Pesisir sub district Pekanbaru City on small investors have a competitive advantage which is characterized by catfish PCR $<1$ of 0.55 and a high comparative advantages characterized by DRCR <1 0.37. Third: government policy towards input subsidy in the form of tradable production facilities give benefits to business of enlarging catfish farmers Rumbai Pesisir sub district Pekanbaru City on the small investor farmers.
\end{abstract}

Keywords: Competitiveness, Catfish, Input-Output, PAM Analysis.

Diterima : 1 Februari 2020. Disetujui: 24 Agustus 2020

Jurnal Ilmiah Pertanian, Vol. 17, No.1, Pebruari 2020 


\section{PENDAHULUAN}

Indonesia merupakan negara yang memiliki tingkat produksi ikan yang cukup tinggi setiap tahunnya, disampaikan oleh Menteri Perikanan dan Kelautan bahwa Indonesia memberi pasokan ikan cukup banyak untuk negara-negara luar negeri. Indonesia menduduki peringkat ke 2 dalam mengekspor ikan di dunia setelah negara china.

Total Volume ekspor untuk hasil perikanan Indonesia mengalamai peningkatan sebesar $6,02 \%$ pada tahun 2012 , dari 1.159 juta ton pada tahun 2011 menjadi sebesar
1.229 juta ton, sedangkan berdasarkan nilai dibandingkan tahun 2011, total nilai ekspor ditandai dengan kenaikan nilai ekspor hasil perikanan tahun 2012 sebesar 9,44\% dari US\$ 3,52 milyar ditahun 2011 menjadi 3,85 Milyar ditahun 2012 (Badan Pusat Statistik, 2013).

Berdasarkan Publikasi Direktorat Jenderal Perikanan Budidaya tahun 2013 menyatakan bahwa produksi perikanan di Indonesia memiliki berbagai jenis budidaya yaitu:budidaya laut, tambak, kolam, kerambah, jaring apung dan sawah Berikut dapat dijelaskan pada tabel 1 .

Tabel 1. Produksi Perikanan Budidaya di Indonesia Tahun 2009-2012

\begin{tabular}{ccccc}
\hline \multirow{2}{*}{ Komoditas } & 2014 & 2015 & 2016 & 2017 \\
\cline { 2 - 5 } & (Ton) & (Ton) & (Ton) & (Ton) \\
\hline Kerapu & $13,345.66$ & $16,795.28$ & $11,503.92$ & $70,294.17$ \\
Kakap & $5,446.56$ & $6,557.96$ & $7,890.22$ & $8,431.38$ \\
Bandeng & $631,124.74$ & $672,195.76$ & $747,445.20$ & $636,825.13$ \\
Patin & $418,001.80$ & $339,069.33$ & $392,918.17$ & $319,966.22$ \\
Nila & $999,694.99$ & $1,084,280.62$ & $1,114,156.31$ & $1,265,200.63$ \\
IkanMas & $434,653.00$ & $461,546.31$ & $497,208.31$ & $312,953.98$ \\
Lele & $679,378.79$ & $719,619.02$ & $764,796.83$ & $1,095,969.33$ \\
Gurami & $118,776.39$ & $113,406.94$ & $132,333.58$ & $220,125.85$ \\
Udang & $639,368.92$ & $607,152.13$ & $692,568.19$ & $1,150,404.95$ \\
Lainnya & $342,346.81$ & $384,194.60$ & $591,197.04$ & $578,776.39$ \\
\hline
\end{tabular}

Sumber: Badan Pusat Statistik Indonesia Tahun 2019

Perkembangan Produksi Perikanan dari tahun 2014 sampai dengan tahun 2017 mengalami perkembangan produksi yang cukup tinggi yakni mencapai $51.49 \%$, kecuali untuk komoditas ikan mas dan Patin yang mengalami penurunan di tahun 2014 sebesar 434.653 ton tahun $2017312.953,98$ ton ($7,88)$ dan . Sedangkan komoditas ikan nila dan ikan lele mengalami peningkatan produksi sebesar 909.747 ton. Sumatera Selatan merupakan salah satu provinsi terbesar penghasil produk perikanan dari budidaya yaitu sebesar 435.001 ton (Ditjen Perikanan Budidaya, 2013). Berikut pada Tabel 2 dijelaskan Sepuluh (10) peringkat provinsi terbesar penghasil perikanan budidaya di Indonesia. 
Tabel 2. Sepuluh peringkat provinsi terbesar penghasil perikanan budidaya di Indonesia Tahun 2017.

\begin{tabular}{ccc}
\hline Provinsi & $\begin{array}{c}\text { Jumlah Produksi } \\
\text { (Ton) }\end{array}$ & Persentase \\
\hline Sulawesi Selatan & $3,897,048$ & 25.10 \\
Nusa Tenggara & $1,953,192$ & 12.58 \\
Timur & $1,148,081$ & 7.40 \\
Jawa Timur & $1,089,987$ & 7.02 \\
Jawa Barat & $1,023,098$ & 6.59 \\
Nusa Tenggara Barat & $1,014,860$ & 6.54 \\
Sulawesi Tenggara & 811,663 & 5.23 \\
Maluku & 740,071 & 4.77 \\
Sulawesi Tengah & 491,203 & 3.16 \\
Sumatera Selatan & 472,174 & 3.04 \\
Kalimantan Utara & $2,882,714$ & 18.57 \\
Provinsi Lainnya & $15,524,091$ & 100.00 \\
Total &
\end{tabular}

Sumber: Badan Pusat Statistik Indonesia Tahun 2019

Walaupun statusnya kota namun Kota Pekanbaru juga mempunyai potensi perikanan, yang tidak sedikit. Ikan bisa diperoleh dari hasil penangkapan di perairan umum maupun hasil budidaya, Wilayah Kota Pekanbaru memiliki daerah perairan seluas $+7.956,58 \mathrm{Ha}$, yang terdiri dari Sungai Siak, beberapa anak sungai yaitu Sungai Sail, Air Hitam, Ukai, Senapelan, Tenayan, Pengambang, Umban Sari yang semuanya bermuara ke Sungai Siak, Danau Buatan dan beberapa daerah rawa-rawa. Produksi ikan di Kota Pekanbaru didominasi oleh hasil budidaya.

Tabel 3. Produksi Ikan Budidaya di Kolam (ton) Kota Pekanbaru Menurut Kecamatan Tahun 2017

\begin{tabular}{lrrrrrrr}
\hline Kecamatan & $\begin{array}{c}\text { Ikan } \\
\text { Lainnya }\end{array}$ & Lele & $\begin{array}{c}\text { Bawal } \\
\text { Tawar }\end{array}$ & Gurami & Nila & Patin & Baung \\
\hline Tampan & 0 & 9.69 & 16.95 & 0 & 0 & 252.95 & 0.77 \\
Payung Sekaki & 0 & 6.55 & 12.45 & 4.21 & 0 & 6.99 & 0 \\
Bukit Raya & 0 & 11.65 & 8.15 & 24.59 & 0 & 59.16 & 0 \\
Marpoyan Damai & 0 & 8.38 & 11.55 & 0.63 & 0 & 10.71 & 0 \\
Tenayan Raya & 0 & 596.96 & 144.33 & 16.96 & 0 & 709.93 & 0.72 \\
Limapuluh & 0 & 0 & 0 & 0 & 0 & 0 & 0 \\
Sail & 0 & 0 & 0 & 0 & 0 & 0 & 0 \\
Pekanbaru Kota & 0 & 0 & 0 & 0 & 0 & 0 & 0 \\
Sukajadi & 0 & 0 & 0 & 0 & 0 & 0 & 0 \\
Senapelan & 0 & 0 & 0 & 0 & 0 & 0 & 0 \\
Rumbai & 0.04 & 489.85 & 60.28 & 56.71 & 2.87 & 945.65 & 0.81 \\
Rumbai Pesisir & 2.82 & 186.33 & 90.15 & 51.09 & 46.14 & 2672.97 & 2.41 \\
\hline Kota Pekanbaru & 2.86 & 1309.41 & 343.86 & 154.19 & 49.01 & 4658.36 & 4.71 \\
\hline
\end{tabular}

Sumber: Badan Pusat Statistik (Pekanbaru dalam Angka, 2019) 
Tabel diatas menunjukan bahwa ikan lele mendapatkan posisi yang baik yakni menduduki produksi perikat kedua setelah ikan patin. Hal ini memperlihatkan bahwa ikan lele masih banyak peminatnya. Akan tetapi untuk petani pemodal kecil mengalami kesulitan dalam pengembangan usaha, Teknik budidaya yang dilakukan pembesaran ikan inipun bervasiasi sesuai dengan ketersediaan modal Sementara itu, hasil produksi ikan ini juga dipasarkan di luar Kota Pekanbaru, kota pekanbaru merupakan sebagai kota transit perdagangan ikan yang akan dipasarkan untuk kota-kota sekitarnya seperti Pangkalan Kerinci, Siak dan Perawang.

Ikan lele merupakan salah satu alternatif komoditas unggulan air tawar yang penting dalam rangka pemenuhan peningkatan gizi masyarakat kebutuhan akan pangan pokok (Djami, Heriyanto, \& Elinur, 2012; Elinur, Asrol, \& Heriyanto, 2017; Heriyanto, 2016). Agribisnis Lele adalah suatu kegiatan usaha/bisnis yang berkaitan dengan ikan lele sebagai komoditas utamanya. Bisnis lele sekarang ini tengah marak dan bekembang pesat. Pasar utama ikan lele adalah warung lesehan dan pecel lele, disamping itu lele segar ataupun aneka olahan ikan lele mulai banyak dijumpai di restoran, supermarket dan industri olahan. Dengan meningkatkan Permintaan Ikan lele Maka Petani ikan Lele Berusaha Meningkatkan produksinya. Produksi Ikan lele dikota Disajikan Pada Tabel 2. Di kota Pekanbaru bisa Pemeliharaan kolam disetiap Kecamatan Di Kota Pekanbaru.

Tabel 4. Banyak Produksi Ikan Lele Peliharaan Kolam Menurut Kecamatan Di Kota Pekanbaru (Ton) Tahun 2012 2016.

\begin{tabular}{rlrrrrrr}
\hline No & Kecamatan & \multicolumn{1}{c}{2012} & \multicolumn{1}{c}{2013} & \multicolumn{1}{c}{2014} & \multicolumn{1}{c}{2015} & \multicolumn{1}{c}{2016} & Pertumbuhan \\
\hline 1 & Tampan & 10,59 & 76,75 & 9,69 & 252,95 & 269,13 & 0,91 \\
2 & Payung sekaki & 9,55 & 2,06 & 6,55 & 6,99 & 7,43 & $-0,05$ \\
3 & Bukit raya & 9,77 & 17,90 & 11,65 & 59,16 & 62,95 & 0,45 \\
4 & Marpoyan damai & 4,67 & 3,27 & 8,38 & 10,71 & 11,40 & 0,20 \\
5 & Tenayan raya & 3,37 & 215,35 & 596,96 & 709,93 & 755,34 & 1,95 \\
6 & Lima puluh & 3,06 & 0,00 & 0,00 & 0,00 & 0,00 & $-1,00$ \\
7 & Sail & 2,88 & 0,00 & 0,00 & 0,00 & 0,00 & $-1,00$ \\
8 & Pekanbaru kota & 0,00 & 0,00 & 0,00 & 0,00 & 0,00 & 0,00 \\
9 & Sukajadi & 0,00 & 0,00 & 0,00 & 0,00 & 0,00 & 0,00 \\
10 & Senapelan & 0,00 & 0,00 & 0,00 & 0,00 & 0,00 & 0,00 \\
11 & Rumbai & 0,00 & 286,86 & 489,85 & 945,65 & $1.006,13$ & 0,29 \\
12 & Rumbai pesisir & 0,00 & 810,88 & 186,33 & $2.672,97$ & $2.843,94$ & 0,29 \\
\hline & Jumlah & 439,00 & $1.413,07$ & $1.309,41$ & $4.658,36$ & $4.956,32$ & 0,62 \\
\hline
\end{tabular}

Sumber:Badan Pusat Statistik (Pekabaru dalam Angka, 2019).

Berdasarkan Tabel 4 dapat diketahui banyaknya produksi ikan lele pemeliharaan kolam Dikota Pekanbaru (Ton). Produksi ikan lele yang tertinggi pada tahun 2016 jumlah pemeliharaan kolam sebesar 4.956,32 Ton, dan Jumlah yang terendah pada tahun 2012 jumlah pemeliharaan kolam 439,00 Rumbai Pesisir Salah Satu Kelurahan penghasil ikan lele. Rumbai Pesisir Berpotensi untuk di kembangkan usaha budidaya ikan lele (Badan Pusat Statistik, 2017).

Permasalahan-permasalahan yang masih dirasakan berkaitan dengan pengembangan usaha perikanan antara lain: (1) Masih kurangnya pengetahuan, keterampilan dan pengalaman pembudidaya dalam budidaya ikan; (2) Kegiatan pengolahan ikan masih banyak yang bersifat 
tradisional dan musiman sehingga ketersediaan produk hasil olahan tidak stabil; (3) Masih banyak terdapat kolam ikan menjadi lahan tidur (tidak dioperasionalkan) disebabkan karena kekurangan biaya; (4) Tingginya harga pakan pabrikan (pelet) yang menyebabkan kurang gairahnya pembudidaya ikan melakukan usaha budidaya.

Berdasarkan uraian diatas pada latar belakang, secara umum penelitian ini bertujuan untuk: 1) Menganalisis daya saing pembesaran ikan lele. Adapun secara spesifik penelitian ini bertujuan untuk menganalisis mengetahui karakteristik petani, 2) menganalisis Daya Saing Usaha Pembesaran Ikan lele, 3) Menganalisis dampak kebijakan pemerintah terhadap output dan input didalam usaha pembesaran ikan lele.

\section{METODE PENELITIAN}

Penelitian ini merupakan penelitian survey yang digunakan untuk mendapatkan atau mengumpulkan informasi langsung dari sekelompok individu atau sampel dan sampel ini merupakan bagian dari populasi yang menjadi objek penelitian. Penentuan lokasi penelitian dilakukan dengan sengaja di di Kecamatan Rumbai Pesisir Kota Pekanbaru dengan pertimbangan bahwa Kabupaten Musi Rawas merupakan salah satu kawasan minapolitan yang ada di Sumatera Selatan. Data yang digunakan dalam penelitian ini adalah data di tahun 2017. Populasi dalam penelitian ini adalah pembudidaya ikan lele dan pengusaha ikan lele yang berada di Kecamatan Rumbai Pesisir yang terdiri dari enam (6) Kelurahan yaitu: Meranti Pandak, Lembah Sari, Tebing Tinggi Okura,
Limbungan, Limbungan Baru dan Lembah Damai. Metode penentuan responden adalah dengan metode Purpossive yaitu sengaja dilakukan sesuai dengan kriteria yang telah ditetapkan oleh peneliti yakn:

Kriteria responden untuk pembudidaya pemodal kecil adalah sebagai berikut:

a) Petani pemilik kolam ikan lele air tenang

b) Usaha ikan lele dengan luas lahan kolam rata-rata $500 \mathrm{~m}^{2}-2.500 \mathrm{~m}^{2}$ dengan

c) kedalaman $0,5 \mathrm{~m}-1,5 \mathrm{~m}$

d) Kapasitas ikan per kolam 5.000 - 25.000 bibit ikan ( $1,5 \mathrm{~kg}-9 \mathrm{~kg})$

e) Ukuran ikan yang dimasukkan kedalam kolam 3.000 ekor / kg

f) Merupakan anggota kelompok yang mendapatkan bantuan dari pemerintah

g) Lama Pembesaran ikan $4-5$ bulan

h) Produksi ikan 3 - 4 ekor $/ \mathrm{kg}$.

Cara menentukan jumlah responden yakni dengan cara purpossive dengan pertimbangan bahwa populasi petani ikan sudah homogen dan sesuai dengan kebutuhan penelitian, menurut Ridwan \& Sunarto, (2009) paling sedikit $10 \%$ dalam menentukan jumlah responden. Pada penelitian ini digunakan sebanyak $30 \%$ dari jumlah populasi yakni untuk petani pemodal kecil $30 \%$ x 50 orang = 15 orang

Metode pengambilan responden dilakukan dengan metode Proportonate Stratified Random Sampling menurut Sugiyono (2008), Pengambilan responden untuk petani pemodal kecil di Kecamatan Rumbai Pesisir yakni: 
Tabel 5. Populasi dan Responden

\begin{tabular}{clcc}
\hline No & \multicolumn{1}{c}{ Kelurahan } & Populasi & Sampel \\
\hline 1 & Meranti Pandak & 5 & 2 \\
2 & Lembah sari & 17 & 5 \\
3 & Tebing Tinggi Okura & 12 & 4 \\
4 & Limbungan & 4 & 1 \\
5 & Limbungan Baru & 2 & 1 \\
6 & Limbah Damai & 10 & 3 \\
\hline Jumlah & 50 & 15 \\
\hline
\end{tabular}

Data yang digunakan pada penelitian ini adalah data primer dan data sekunder.

a) Data primer dalam penelitian ini adalah wawancara kepada sejumlah petani, pengusaha dan informan yang terlibat langsung dalam kegiatan usahatani ikan lele dan dengan menggunkan kuisioner yang terstruktur.

b) Data sekunder dikumpulkan dari berbagai literature, dokumen hasil penelitian pada instansi perikanan, BPS, dan stakeholder lainnya yang berupa hasil-hasil penelitian sejenis baik komoditas ataupun alat analisis, data luas lahan kolam ikan serta produksi ikan, dan lainnya yang terkait dengan penelitian.

\section{Analisis Data}

Untuk menganalisis karakteristik petani usahatani ikan lele dilakukan dengan menggunakan metode statistik deskriptif, yaitu metode untuk mengumpulkan, meringkas, menyajikan, dan mendeskripsikan data sehingga memberikan informasi yang berguna (Nisfianoor, 2009). Data yang dikumpulkan kemudian ditabulasi dan diinterpretasikan yang meliputi umur, lama pendidikan, pengalaman usaha, dan jumlah anggota keluarga

Selanjutnya untuk menganalisis daya saing menggunakan analisis PAM (Policy
Anlayisis Matrix) yang telah dikembangkan oleh Monke dan Person sejak tahun 1987. Analisis ini dapat digunakan pada sistem komoditas dengan berbagai wilayah, tipe usahatani, dan teknologi. Selain itu analisis PAM juga dapat digunakan untuk mengetahui apakah suatu kebijakan dapat memperbaiki daya saing terhadap pengusahaan suatu komoditi yang dihasilkan dari penciptaan efisiensi usaha dan pertumbuhan pendapatan.

\section{Analisis Daya saing}

\section{Analisis Keuntungan}

Private Profitability (PP), yaitu D = A- $(\mathrm{B}+\mathrm{C})$. Keuntungan privat merupakan indikator daya saing (competitiveness). Apabila D $>0$, berarti sistem komoditas tersebut memperoleh profit diatas normal. Hal ini mempunyai implikasi bahwa komoditas tersebut mampu ekspansi. Sebaliknya, bila Nilai $\mathrm{D} \leq 0$, berarti sistem komoditas tersebut memperoleh profit dibawah normal dan belum mampu ekspansi.

Sosial Profitability (SP), yaitu $\mathrm{H}=\mathrm{E}-$ $(\mathrm{F}+\mathrm{G})$. Keuntungan sosial merupakan indikator keuntungan komparatif (comparative advantage) atau efisiensi dari sistem komoditas pada kondisi tidak ada divergensi dan penerapan kebijakan yang efisien, apabila $\mathrm{H}>0$. Sebaliknya, bila $\mathrm{H} \leq 0$, berarti sistem komoditas tidak mampu bersaing tanpa bantuan atau intervensi pemerintah. 
Keunggulan Kompetitif PCR dan Keunggulan Komparatif DR

Private Cost Rasio $(\mathrm{PCR})=\mathrm{C} /(\mathrm{A}-\mathrm{B})$

Apabila nilai PCR $<1$ dan nilainya makin kecil, berarti sistem produksi usahatani pembesaran ikan lele semakin kompetitif dan mampu membiayai faktor domestiknya pada harga privat dan kemampuannya tersebut akan meningkat. Sebaliknya bila, PCR $\geq 1$, sistem komoditas yang diteliti tidak memiliki keunggulan kompetitif.

Domestic Resources Cost Ratio $(\mathrm{DRCR})=$ $\boldsymbol{G} /(\boldsymbol{E}-\boldsymbol{F})$

Jika DRCR < 1, maka sistem komoditas mempunyai keunggulan komparatif. Sebaliknya jika DRCR $\geq 1$ sistem komoditas tidak memiliki keunggulan komparatif.

\section{Dampak Kebijakan Pemerintah}

\section{Kebijakan Terhadap Output}

Output Transfer (OT) : I = A - E

Jika nilai OT $>0$ menunjukkan adanya transfer dari masyarakat (konsumen) kepada produsen, sebaliknya bila OT $\leq 0$, menunjukkan tidak ada transfer dari masyarakat (konsumen) kepada produsen.

\section{Nominal Protection Coefficient on Output $(\mathrm{NPCO})=\mathrm{A} / \mathrm{E}$}

Jika nilai NPCO $>1$. Semakin besar nilai NPCO, berarti semakin besar tingkat proteksi pemerintah terhadap output, sebaliknya bila NPCO $\leq 1$, kebijakan bersifat disinsentif.

\section{Kebijakan Terhadap Input}

Input Transfer (IT) $: J=B-F$

Jika nilai IT $>0$, menunjukkan adanya transfer dari petani pembesaran ikan lele ke produsen kepada input tradable, sebaliknya bila IT $\leq 0$, menunjukkan tidak adanya transfer dari petani ke produsen input tradable Nominal Protection Coefficien on Tradable Input $(N P C I)=B / F . \quad$ NPCI merupakan indicator yang menunjukkan tingkat proteksi pemerintah terhadap harga input domestic. Jika nilai NPCI $<1$, berarti kebijakan bersifat protektif terhadap input, ada kebijakan subsidi terhadap input tradable, sebaliknya bila NPCI $\geq 1$, berarti tidak ada kebijakan protektif terhadap input/ tidak ada kebijakan subsidi terhadap input tradable Transfer Factor b. Transfer Factor $(T F): K=C-G$

Transfer faktor merupakan nilai yang menunjukkan perbedaan harga privat dengan harga sosialnya yang diterima produsen untuk pembayaran faktor-faktor produksi yang tidak diperdagangkan ( non tradable). Nilai TF > 0 berarti bahwa ada transfer dari petani kepada produsen input non tradable atau pemerintah, sebaliknya bila $\mathrm{TF} \leq 0$ berarti tidak ada transfer dari petani kepada produsen input non tradable.

\section{Kebijakan Terhadap Input-Output}

Effective Protection Coefficient $($ EPC $)=(\mathrm{A}-$ B) / $(\mathbf{E}-\mathbf{F})$

EPC merupakan indikator yang menunjukkan tingkat proteksi simultan terhadap output dan input tradable. Kebijakan masih bersifat protektif, jika nilai EPC $>1$. Semakin besar nilai EPC, berarti semakin tinggi tingkat proteksi pemerintah terhadap komoditas domestik.

Net Transfer (NT): L $=\mathrm{D}-\mathrm{H}$

Transfer bersih merupakan selisih antara keuntungan bersih yang benar-benar diterima produsen dengan keuntungan bersih sosialnya. Nilai NT > 0 , menunjukkan tambahan surplus produsen yang disebabkan oleh kebijakan pemerintah yang diterapkan pada input dan output, demikian juga sebaliknya. 


\section{Profitability Coefficient $(\mathbf{P C})=\mathrm{D} / \mathrm{H}$}

Koefisien keuntungan adalah perbandingan antara keuntungan bersih yang benar-benar diterima produsen dengan keuntungan bersih sosialnya. Jika PC >0, berarti secara keseluruhan kebijakan pemerintah memberikan insentif kepada konsumen, demikian juga sebaliknya.

\section{Subsidy Ratio to Producer $(\mathrm{SRP})=\mathrm{L} / \mathrm{E}$}

Rasio subsidi produsen (SRP) merupakan indikator yang menunjukkan proporsi penerimaan pada harga sosial yang diperlukan apabila subsidi atau pajak digunakan sebagai pengganti kebijakan. Nilai SRP yang negatif menunjukkan bahwa kebijakan pemerintah yang berlaku selama ini menyebabkan produsen mengeluarkan biaya produksi lebih besar dari biaya imbangan (opportunity cost) untuk berproduksi dan sebaliknya jika nilai SRP positif.

\section{HASIL DAN PEMBAHASAN}

\section{Karakteristik Petani Usaha Pembesaran Ikan Lele}

Pada usahatani budidaya ikan lele terdiri dari petani pemodal kecil. Berikut adalah karakteristik responden pada penelitian tentang daya saing usahatani budidaya ikan lele pemodal kecil yang amati meliputi umur, tingkat pedidikan, pegalaman berusaha tani, pendidikan, jumlah anggota keluarga, luas lahan usaha tani yang dapat dilihat pada Tabel 5.

Dari Tabel diatas menunjukan bahwa karakteristik petani rata-rata umur petani 41 tahun, berpendidikan rendah, pengalaman usahatani 8 tahun, rata-rata kepemilikan lahan 0,19 hektar. dan rata-rata jumlah anggota keluarga 3 jiwa.

Tabel 6. Karakteristik Usaha Pembesaran Ikan Lele

\begin{tabular}{|c|c|c|c|c|}
\hline \multirow[b]{2}{*}{ No } & \multirow[b]{2}{*}{ Uraian Karakteristik } & \multicolumn{3}{|c|}{ Pemodal Kecil } \\
\hline & & Frekuensi & $\%$ & $\begin{array}{c}\text { Rata- } \\
\text { rata }\end{array}$ \\
\hline \multirow[t]{5}{*}{1} & Umur (Tahun) & & & \\
\hline & a. Muda (29-35) & 4 & 26,67 & \\
\hline & b. Sedang $(36-42)$ & 5 & 33,33 & 41 \\
\hline & c. Tua (43-50) & 6 & 40 & \\
\hline & Total & 15 & 100 & \\
\hline \multirow[t]{8}{*}{2} & Pendidikan & & & \\
\hline & a. SD & 3 & 20 & \\
\hline & b. SMP & 5 & 33,33 & \\
\hline & c. SMA & 5 & 33,33 & \\
\hline & d. D1 & $\mathbf{O}$ & $\mathbf{O}$ & \\
\hline & e. D2 & 1 & 6,667 & \\
\hline & f. $\mathrm{S} 1$ & 1 & 6,667 & \\
\hline & Total & 15 & 100 & \\
\hline \multirow[t]{5}{*}{3} & Jumlah Tanggungan K & ga (Orang) & & \\
\hline & a. Sedikit (1) & 1 & 6,667 & \\
\hline & b Sedang (2) & 6 & 40 & 3 \\
\hline & c. Banyak (3) & 8 & 53,33 & \\
\hline & Total & 15 & 100 & \\
\hline \multirow[t]{5}{*}{4} & Pengalaman Usahatan & iun) & & \\
\hline & a. Baru $(3-6)$ & 6 & 40 & \\
\hline & b. Sedang (7-10) & 6 & 40 & 8 \\
\hline & c. Lama ( $111-15)$ & 3 & 20 & \\
\hline & Total & 15 & 100 & \\
\hline \multirow[t]{5}{*}{5} & Luas Lahan (Hektar) & & & \\
\hline & a. Sempit $(0,25-0,50)$ & 11 & 73,33 & \\
\hline & b. Sedang $(0,51-0,75)$ & 2 & 13,33 & 0,19 \\
\hline & c. Luas $(0,76-1)$ & 2 & 13,33 & \\
\hline & Total & 15 & 100 & \\
\hline
\end{tabular}


Analisis Daya Saing Usaha Pembesaran Ikan Lele

Pendekatan yang digunakan untuk mengukur daya saing suatu komoditas dapat dilihat dari keuntungan kompetitif dan komparatif. Salah satu alat analisis yang dapat digunakan untuk mengetahui daya saing suatu komoditi (keunggulan kompetitif dan keunggulan komparatif) adalah matriks analisis kebijakan atau PAM (Policy Analysis Matriks) yang disusun berdasarkan data penerimaan, biaya produksi dan biaya lainnya yang dihitung berdasarkan harga finansial (privat) dan harga ekonomi (bayangan atau sosial). Masing-masing biaya produksi pada harga finansial dan ekonomi dibagi menjadi komponen tradable (asing) dan non tradable (domestik). Kajian yang terdahulu tentang daya saing kebanyakan hanya menganalisis komparatif yaitu Anggit, 2012; Apridar, 2014; Asrol \& Heriyanto, 2018; Effendi \& Suhartini, 2017; Fitriana, 2014a, 2014b; Gentimir \&
Gentimir, 2015; Gururaj, Satishkumar, \& Aravinda Kumar, 2016; Hidayati \& Suhartini, 2018; Karagoz, 2016; Maulana \& Kartiasih, 2017; Muharami \& Novianti, 2018; Neuzil, 2006; Prasetyo \& Marwanti, 2017; Rajagukguk, 2009; Sadikin I, 2002; Sinaga, Napitupulu, \& Yusma Damayanti, 2017; Sunardi, Oktaviani, \& Novianti, 2014; Syahputra, Tarumun, \& Yusri, 2014; Teguh, 2015; Utami \& Yulianto, 2018; Wahono, 2015; Wayan, Abidin, \& Santoso, 2013; Yuniarti \& Sam'un Jaja Raharja, 2016; Zuhdi \& Agribisnis, 2016;Dang \& Yeo, 2017;Heriyanto, Karya, \& Asrol, 2019;Ningsih et al (2020). Kajian ini selain menganalisis keunggulan komparatif juga menganalisis keunggulan kompetiti.

\section{Analisis Keuntungan}

\section{Analisis Keunggulan Kompetitif Usaha Pembesaran Ikan Lele}

Tabel 7. Analisis Keunggulan Kompetitif Matriks PAM

\begin{tabular}{lccl}
\hline Uraian & Simbol & Hasil & Kesimpulan \\
\hline Keungoulan Kompetitif pada pemodal kecil & \\
\hline Privat Profitability & PP & 5.531 .734 & $\begin{array}{l}\text { D }>0 \text { 0, Komoditas ikan nila mampu } \\
\text { ekspansi karena memiliki keuntungan } \\
\text { yang diterima langsung petani }\end{array}$ \\
Privat Cost Ratio & PCR & 0.55 & $\begin{array}{l}\text { PCR }<1, \text { Komoditas yang diteliti } \\
\text { memiliki keunggulan yang kompetitif. }\end{array}$
\end{tabular}

\section{Analisis Keunggulan Komparatif Usaha Pembesaran Ikan lele}

Keunggulan komparatif suatu komoditas ditentukan oleh nilai-nilai keuntungan sosial (SP/Social Provitability) dan nilai ratio sumber daya domestik (DRCR/Domestic Resource Cost Ratio). 
Tabel 8. Analisis Keunggulan Komparatif Matriks PAM

\begin{tabular}{lccl}
\hline Uraian & Simbol & Hasil & Kesimpulan \\
\hline \multicolumn{2}{l}{ Keunggulan Komparatif pada pemodal kecil } & \\
\hline Privat Profitability & SP & 11.378 .507 & $\begin{array}{l}\text { SP }>0 \text {, ada efisiensi dari sistem komoditas } \\
\text { pada kondisi tidak divergensi dan } \\
\end{array}$ \\
& & penerapan kebijakan efisiens. \\
& & DRCR $<1$, Komoditas yang diteliti \\
& 0.37 & memiliki keunggulan yang komparatif.
\end{tabular}

Hasil analisis dengan metode PAM menunjukkan bahwa nilai keuntungan sosial/SP untuk usaha pembesaran ikan lele pada pemodal kecil di Kecamatan Rumbai Pesisir Kota Pekanbaru adalah Rp. 11.378.507 ini menunjukkan bahwa usaha pembesaran ikan lele layak diusahakan dan memiliki keuntungan komparatif. Keuntungan sosial adalah keuntungan yang diperoleh jika terjadi pasar persaingan sempurna, dimana tidak ada campur tangan pemerintah dan kegagalan pasar.

Nilai ratio sumber daya domestik/DRCR usaha pembesaran ikan lele pada pemodal kecil di Kecamatan Rumbai Pesisir Kota Pekanbaru berdasarkan hasil analisis adalah 0,37, nilai tersebut menunjukkan bahwa untuk mendapatan 1 unit nilai tambah diperlukan biaya domestik sebesar 0.11 unit pada usaha pembesaran ikan lele pada pemodal kecil di Kecamatan Rumbai Pesisir Kota Pekanbaru. Hal ini usaha pembesaran ikan lele dapat menambah pendapatan rumahtangga (Asrol dan Heriyanto, 2019).

\section{Dampak Kebijakan Pemerintah}

Setiap negara berkembang memiliki kebijakan pemerintah pada sektor pertanian sehingga dapat menetukan keberhasilan pengembangan dan usaha dalam rangka menambah devisa negara. Suatu kebijakan pemerintah dalam suatu aktivitas ekonomi dapat meberikan dampak positif dan negatif terhadap pelaku ekonomi.

\section{Dampak Kebijakan Pemerintah Terhadap Output}

Kebijakan pemerintah berupa subsidi dan pajak pada suatu komoditas agribisnis dapat berpengaruh positif dan negatif bagi para pelakunya. Indikator dampak kebijakan pemerintah terhadap output dapt dilihat dengan menggunkan nilai OT (Output Transfer) dan NPCO (Nominal Protection Coefficient On Output). 
Tabel 9. Dampak Kebijakan Pemerintah Terhadap Output

\begin{tabular}{llll}
\hline Uraian & Simbol & Hasil & Kseimpulan \\
\hline \multicolumn{2}{l}{ Kebijakan Ouput Petani Pemodal Kecil } \\
\hline $\begin{array}{l}\text { Output Transfer } \\
\text { OT }\end{array}$ & 5.910 .481 .48 & $\begin{array}{l}\text { Tidak adanya transfer dari masyarakc } \\
\text { (Konsumen) ke Produsen }\end{array}$ \\
$\begin{array}{l}\text { Nominal Protection } \\
\text { Coefficient Output }\end{array}$ & NPCO & 0.91 & Kebijakan bersifat disinsetif \\
\hline
\end{tabular}

Hasil analisis metode PAM diketahuibahwa nilai OT pada usaha pembesaran ikan lele adalah negatif artinya harga privat pada pemodal besar dan pemodal kecil lebih rendah daripada harga sosialnya. Kondisi ini menunjukkan bahwa adanya intervensi pemerintah pada output terhadap usaha pembesaran ikan lele ini lebih menguntungkan konsumen, karena konsumen membeli harga yang lebih rendah dari harga sebenarnya. Dengan kata lain, terjadi pengalihan surplus dari produsen ke konsumen.

\section{Dampak kebijakan pemerintah terhadap input}

Kebijakan pemerintah tidak saja berlaku untuk output namun berlaku pula untuk harga input. Adapun indikatorindikator yang digunakan untuk melihat intervensi pemerintah terhadap input produksi adalah nilai transfer (IT), Transfer Faktor (TF), dan koefisien proteksi nominal pada input/Nominal Protection Coefisien on Tradabel Input.

Tabel 10. Dampak kebijakan Pemerintah terhadap Input

\begin{tabular}{llll}
\hline Uraian & Simbol & Hasil & Kesimpulan \\
\hline \multicolumn{2}{l}{ Kebijakan Input Pada Pemodal Kecil } & & \\
Input Transfer & IT & $45,670,801.48$ & $\begin{array}{l}\text { Menunjukkan tidak adanya transfer } \\
\text { dari petani ke produsen input tradable }\end{array}$ \\
Transfer Factor & TF & $12,526.60$ & $\begin{array}{l}\text { Adanya transfer dari petani produsen } \\
\text { ke produsen input tradable }\end{array}$
\end{tabular}

Hasil analisis dengan menggunakan metode PAM diketahui bahwa nilai IT adalah negatif. Nilai IT menggambarkan kebijakan subsidi atau pajak yang terjadi pada input tradable. Nilai negatif untuk usaha pembesaran ikan lele menunjukkan bahwa terdapat kebijakan subsidi terhadap input produksi tradable dalam usaha pembesaran ikan lele. Hal tersebut menguntungkan bagi petani budidaya ikan lele karena terdapat kebijakan pemerintah berupa subsidi atas input tradable yang menyebabkan harga yang dibayarkan petani terhadap input tersebut lebih rendah dari harga sebenarnya.

\section{KESIMPULAN}

a) Karakteristik petani rata-rata umur petani 41 tahun, berpendidikan rendah, pengalaman usahatani 8 tahun, rata-rata kepemilikan lahan 0,19 hektar. dan ratarata jumlah anggota keluarga 3 jiwa.

b) Usaha pembesaran ikan lele di Kecamatan Rumbai Pesisir Kota Pekanbaru pada pemodal kecil memiliki keunggulan 
kompetitif yang ditandai dengan lele PCR $<1$ sebesar 0,55 dan memiliki keunggulan komparatif yang tinggi ditandai dengan nilai DRCR $<1$ sebesar 0,37.

c) Kebijakan pemerintah terhadap input sarana produksi tradable berupa subsidi sangat meberikan manfaat pada petani usaha pembesaran ikan lele di Kecamatan Rumbai Pesisir Kota Pekanbaru pada petani pemodal kecil.

\section{DAFTAR PUSTAKA}

Anggit, R. (2012). Analisis Daya Saing Crude Palm Oil (CPO) Indonesia di Pasar Internasional. Jurnal Fakultas Pertanian, Universitas UPN "Veteran," 9(1), 125-133.

Apridar. (2014). Daya Saing Ekspor Ikan Tuna Indonesia. Jakarta: Penerbit Graha Ilmu.

Asrol, A., \& Heriyanto, H. (2018). Daya Saing Ekspor Pala Indonesia di Pasar Internasional. Dinamika Pertanian, 22(2), 61-70. Retrieved from http://journal.uir.ac.id/index.php/dinami kapertanian/article/view/2193

Asrol, \& Heriyanto. (2019). Structures of revenue, expenditure, and welfare of household farmers in kampar regency, riau indonesia. WSEAS Transactions on Business and Economics, 16, 1-8.

Badan Pusat Statistik. (2013). Laporan Produksi Perikanan Budidaya. Jakarta: Badan Pusat Statistik Indonesia.

Badan Pusat Statistik. (2017). Pekanbaru Dalam Angka. Kota Pekanbaru: Badan Pusat Statistik.

Dang, V. L., \& Yeo, G. T. (2017). A Competitive Strategic Position Analysis of Major Container Ports in Southeast Asia. The Asian Journal of Shipping and Logistics, 33(1), 19-25.
Ditjen Perikanan Budidaya. (2013). Laporan Produksi Perikanan Budidaya. Jakarta: Direktorat Jenderal Perikanan Budidaya.

Djami, Heriyanto, H., \& Elinur. (2012). Dampak Pengendalian Harga dan Peningkatan Pendapatan Terhadap Pengeluaran Konsumsi Pangan Pokok Rumahtangga di Provinsi Riau. In Prosiding Seminar Nasional Dies Natalis XIII MMA UGM (pp. 304-310). Yogyakarta: MMA UGM Yogyakarta.

Effendi, R. R., \& Suhartini. (2017). Analisis Daya Saing Ekspor Biji Kopi Indonesia di Pasar Asean Dalam Menghadapi Masyarakat Ekonomi Asean (MEA). JEPA-Jurnal Ekonomi Pertanian Dan Agribisnis, I(1), 22-32.

Elinur, Asrol, \& Heriyanto. (2017). Household Economic Behavior of Rice Farmers Rambah Samo in District of Rokan Hulu Riau Province. In Proceeding International Conference on Science Engineering and Technology (ICoSET) and International Conference on Social Economic Education and Humaniora (ICoSEEH) (pp. 197-2011). Pekanbaru: Universitas Islam Riau.

Fitriana, N. (2014a). Analisis Daya Saing Ekspor Biji Kakao (Cocoa Beans) Indonesia di Pasar Internasional.

Fitriana, N. (2014b). Analisis Daya Saing Ekspor Biji Kakao (Cocoa Beans) Indonesia di Pasar Internasional. Skripsi Fakultas Pertanian, Universitas Riau, Pekanbaru. (Tidak dipublikasikan).

Gentimir, I., \& Gentimir, R. (2015). International competitiveness, growth and socio-economic development in India, 20(15), 252-258. https://doi.org/10.1016/S22125671(15)00072-6 
Gururaj, B., Satishkumar, M., \& Aravinda Kumar, M. K. (2016). Analysis of factors affecting the performance of exports in India. International Journal of Agriculture, Environment and Biotechnology, 9(4), 613-616. https://doi.org/10.5958/2230-

732X.2016.00079.6

Heriyanto, H. (2016). Prilaku Konsumsi Pangan Sumber Karbohidrat Rumahtangga Petani Kelapa Sawit di Kecamatan Kandis Kabupaten Siak. Jurnal Ilmiah Pertanian, 13(2), 22-30. https://doi.org/http://doi.org/10.5281/zen odo. 1222080 .

Heriyanto, H. (2018). Indonesian Coconut Competitiveness In International Markets. Asia Proceedings of Social Sciences, 1(3), 46-50.

Heriyanto, H., Karya, D., \& Asrol, A. (2019). Indonesian coconut competitiveness in international markets. International Journal of Recent Technology and Engineering, 8(2 Special Issue), 102113.

https://doi.org/10.31580/apss.v1i3.390

Hidayati, T. N., \& Suhartini. (2018). Analisis Daya Saing Ekspor Pisang (Musa Paradiaca L.) Indonesia di Pasar Asean Dalam Menghadapi Masyarakat Ekonomi Asean (MEA). Jurnal Ekonomi Pertanian Dan Agribisnis (JEPA) V, 2(4), 267-278.

Karagoz, K. (2016). Determining Factors of Turkey ' s Export Performance: An Empirical Analysis, 38(October 2015), 446-457. https://doi.org/10.1016/S22125671(16)30216-7

Maulana, A., \& Kartiasih, F. (2017). Analisis Ekspor Kakao Olahan Indonesia ke Sembilan Negara Tujuan Tahun 2000 2014. Jurnal Ekonomi Dan Pembangunan Indonesia, 17(2), 103-
117.

https://doi.org/http://dx.doi.org/10.21002 /jepi.v17i2.664

Muharami, G., \& Novianti, T. (2018). Analisis Kinerja Ekspor Komoditas Karet Indonesia Ke Amerika Latin. Jurnal Agribisnis Indonesia, 6(1), 1-12.

Neuzil, P. (2006). Analisis Daya Saing Ekspor Pisang (Musa Paradiacal.) Indonesia di Pasar Asean Dalam Menghadapi Masyarakat Ekonomi Asean (MEA). Nucleic Acids Research, 34(11), e77e77.

Nisfianoor. (2009). Pengantar Statistik. Jakarta: Salemba Humanika.

Ningsih, V., Wahyuni, N., Suryati, N., Noviyanto, N., \& Heriyanto, H. (2020). Competitiveness Sensitivity of Oil Palm Farming on Suboptimal Land at Musi Rawas Residence. Journal of Applied Agricultural Science and Technology, 4(1), 26-35. https://doi.org/10.32530/jaast.v4i1.147. https://kinfopolitani.com/index.php/JAA ST/issue/view/8

Prasetyo, A., \& Marwanti, S. (2017). Keunggulan Komparatif dan Kinerja Ekspor Minyak Sawit Mentah Indonesia di Pasar Internasional. Jurnal Agro Ekonomi, 35(2), 89-103. https://doi.org/DOI:

http://dx.doi.org/10.21082/jae.v35n2.20 17.89-103

Rajagukguk, M. . (2009). Analisis Daya Saing Rumput Laut Indonesia di Pasar Internasional. Bogor: Skripsi Fakultas Ekonomi Dan Manajemen, Institut Pertanian Bogor, Bogor (Tidak dipublikasikan).

Ridwan, \& Sunarto. (2009). Pengantar Statistika Untuk Penelitian Pendidikan, Sosial Ekonomi, Komunikasi dan Bisnis. 
Bandung: Penertbit Alfabeta.

Sadikin I. (2002). Analisis Daya Saing Komoditi Jagung dan Dampak Kebijakan Pemerintah Terhadap Agribisnis Jagung Nusa Tenggara Barat Pasca Krisis Ekonomi. Bogor: Pusat Penelitian Dan Pengembangan Sosial Ekonomi Pertanian, Kementerian Pertanian Republik Indonesia.

Sinaga, I. D. B., Napitupulu, D., \& Yusma Damayanti. (2017). Analisis Daya Saing Ekspor Pinang Provinsi Jambi dan Faktor- Faktor Yang Mempengaruhinya. Jurnal Ilmiah Sosio-Ekonomika Bisnis, 20(2), 1-11. https://doi.org/doi.org/10.22437/jiseb.v2 $0 \mathrm{i} 2$ ANALISIS

Sunardi, D., Oktaviani, R., \& Novianti, T. (2014). Analisis Daya Saing dan Faktor Penentu Ekspor Komoditas Unggulan Indonesia $\mathrm{Ke}$ Organisasi Kerjasama Islam (OKI). Jurnal Ekonomi Dan Kebijakan Pembanguan, 3(2), 95-110.

Syahputra, Y. R., Tarumun, S., \& Yusri, J. (2014). Analisis Daya Saing Ekspor Karet Alam (Natural Rubber) Indonesia di Pasar Internasional. Jurnal Online Mahasiswa (JOM) Bidang Pertanian, 1(2), 1-9.

Teguh, M. (2015). Mengukur Daya Saing Output Di Pasaran Internasional: Komoditi Tunggal Atau Output Industri Sejenis. Jurnal Manajemen \& Bisnis Sriwijaya, 13(4), 499-506.

Utami, T. A., \& Yulianto, E. (2018). Analisis Daya Saing Ekspor Biji dan Produk Olahan Kakao Indonesia ( Periode Tahun 2012-2016 ), 62(2), 11-20.
Wahono, U. (2015). Daya Saing Ekspor Tuna Kaleng Indonesia di Uni Eropa Tahun 2003-2013. Economics Development Analysis Journal, (Vol 4 No 4 (2015)), 427-434.

Wayan, H. N., Abidin, Z., \& Santoso, H. (2013). Analisis Daya Saing Usahatani Kelapa Sawit Di Kecamatan Waway Karya Kabupaten Lampung Timur. Jurnal II A, 1(1), 20-35.

Yuniarti, Y., \& Sam'un Jaja Raharja. (2016). Factor Analysis of Footwear Industry Competitiveness Cibaduyut Bandung. Jurnal AdBispreneur, 1(3), 243-250.

Zuhdi, F., \& Agribisnis, D. (2016). Analisis Daya Saing Ekspor Kopi Indonesia Dan Vietnam Di Pasar Asean 5 Competitiveness Analysis of Indonesian and Vietnam Coffee Export in Asean 5 Market. Habitat, 26(3), 152-162. Retrieved from file:///C:/Users/Adilla/Downloads/208667-2-PB.pdf 